\title{
ISSR as a tool to support taxonomic decisions: a first approach for Chascolytrum species complexes (Poaceae)
}

\begin{abstract}
Chascolytrum Desv. is a South American grass genus, with extension up to Central America, which presents several taxonomic controversies concerning genera and species circumscriptions. Morphological studies were not able to provide robust elements for taxonomic decisions in some species complexes. It was the case of Chascolytrum subaristatum and morphological allies, and of Chascolytrum rufum plus the acceptance (or rejection) of two varieties. In order to provide additional elements for taxonomic decisions in these species complexes, it was performed a preliminary survey using Inter Simple Sequence Repeat (ISSR) markers. Nine primers were used to build similarity dendrograms, and 25 collections were included, analysed in two separated complexes. ISSR were able to separate the two varieties of Chascolytrum rufum, supporting their acceptance. Two species recently described could be clearly separated from their morphologically related taxa, but the species Briza erecta, Briza macrostachya and Chascolytrum subaristatum, as well as Briza subaristata var. interrupta, could not be separated, adding elements to the synonymization of these three taxa under Chascolytrum subaristatum. The ISSR contributed to solving some controversies on genus Chascolytrum, but its use as an exclusive species-marker is limited in this genus due to high band polymorphism.
\end{abstract}

Keywords: Briza, molecular marker, Poeae, systematics.

\section{ISSR como uma ferramenta para apoiar decisões taxonômicas: uma abordagem preliminar para complexos de espécies em Chascolytrum (Poaceae)}

\section{RESUMO}

Chascolytrum Desv. é um gênero sul-americano de gramíneas, com extensão da distribuição até a América Central, o qual apresenta diversas controvérsias taxonômicas com relação à circunscrição de gêneros e espécies. Estudos morfológicos não foram capazes de fornecer elementos robustos para a tomada de decisões taxonômicas em relação a alguns complexos de espécies. Esse foi o caso de Chascolytrum subaristatum $e$ espécies morfologicamente afins, $e$ de Chascolytrum rufum com relação à aceitação (ou rejeição) de duas variedades. Para fornecer elementos adicionais para decisões taxonômicas nesses complexos de espécies, foi realizado um estudo preliminar utilizando marcadores do tipo Inter Simple Sequence Repeat (ISSR). Foram utilizados nove primers para construir dendrogramas de similaridade, e 25 coletas foram incluídas, analisadas em dois complexos distintos. Os marcadores ISSR foram capazes de separar as duas variedades de Chascolytrum rufum, apoiando a aceitação das mesmas. Duas espécies recentemente descritas puderam ser claramente separadas de seus táxons morfologicamente relacionados, porém as espécies Briza erecta, Briza macrostachya e Chascolytrum subaristatum, bem como Briza subaristata var. interrupta, não foram discriminadas nos dendrogramas, $o$ que adiciona elementos para justificar a sinonimização desses três táxons sob Chascolytrum subaristatum. Os ISSR contribuíram para a resolução de algumas controvérsias taxonômicas no gênero Chascolytrum, mas seu uso como um marcador para espécies é limitado no gênero devido ao alto polimorfismo de bandas.

Palavras-chave: Briza, marcador molecular, Poeae, sistemática.

\footnotetext{
*Autor para correspondência

${ }^{1}$ Universidade Federal de Santa Maria
} 


\section{INTRODUCTION}

Chascolytrum Desv. lato sensu (Poaceae) is a morphologically diverse and taxonomically controversial grass genus from subtropical and highland areas in South America, some species presenting potential to use as forage, and also there are endangered species. It is represented by perennial species, caespitose or rhizomatous, with extravaginal basal innovations, spikelets many-flowered and panicles open to contracted, erect or pendulous. The spikelets are very variable inside the genus, and this is one of the reasons that made authors propose several different circumscriptions for this alliance of species. These species can be placed into several other genera, like Briza L. lato sensu, Poidium Nees or Lombardochloa Roseng. \& B. R. Arrill., according to each author. Its evolutionary history was recently analysed (Essi, Longhi-Wagner and Souza-Chies, 2008), and a proposal of a lato sensu circumscription was done, excluding only the euroasiatic species (Essi, Longhi-Wagner andSouza-Chies, 2011). Some taxa presents delimitation controversies, forming species complexes not clarified with morphological studies. It is not clear, for instance, whether species like Briza erecta Lam. and Brizamacrostachya (J. Presl) Steud. should be treated as separate taxa, as done by Longhi-Wagner (1987), or whether they represent only intra-specific variation, and should be synonymised, as proposed by Matthei (1975). The occurrence of several intermediates further complicates this case: morphological links can group these two species with the broadly distributed Briza subaristata Lam. (here treated as Chascolytrum subaristatum (Lam.) Desv.).There is also no consensus whether varieties distinguishable only byspikelet measures, like B. subaristata var. interrupta (Hack. ex Stuck.) Roseng.,Arrill. \&Izag.orbased on single discrete characters, like B. rufa var. sparsipilosa Roseng., Arrill. \& Izag., should be accepted, or whether their variation is merely intraspecific polymorphism or environment plasticity.

It is often difficult to interpret morphological divergences among closely related taxa. Minor morphological differences can be a result of environmental variation, species polymorphism or even of evolutionary divergence processes, such as genetic isolation or speciation. The presence or absence of trichomes on certain structures, for instance, may be taxonomically negligible for some groups, or be a stable and reliable morphologic marker for other taxa.

Decisions concerning accepting or not certain features such as taxon markers or like establishing a given taxonomic level for a morphologically distinct group may provide to systematics a certain level of subjectivity. In such cases, the addition of extra approaches can bring light and objectivity to the studies.

Inter Simple Sequence Repeat (ISSR) PCR is a fast, cheap approach to genetic characterization and is widely used for ecological (Wu et al., 2004; Poulin, Weller and Sakai, 2005), population (Esselman et al., 1999; Alexander, Liston and Popovich, 2004; Song et al., 2006; Zhang et al., 2013) or phylogenetic studies (Joshi et al., 2000; Bussell, Waycott and Chappill, 2005), as well as in crop cultivar or native plant fingerprinting (Mattioni et al., 2002; Souza et al., 2005). It has been also applied to explore the hybrid origin of species (Ayres and Strong, 2001) and for systematic purposes (Blair, Panaud and McCouch, 1999; Vanderpoorten, Hedenäs and Jacquemart, 2003; Dinelli, 2004; Vergara et al., 2008).

ISSRs have a few advantages over other molecular markers. Their primers annealto SSR (Simple Sequence Repeat) that are abundant throughout the eukaryotic genome and evolve rapidly, and hence may reveal a high level of polymorphism (Zietkiewicz, Rafalski and Labuda, 1994; $\mathrm{Li}$ and Ge, 2001). In addition, ISSR may produce more reliable and reproducible bands than RAPD (Random Amplified Polymorphic DNA), due to the higher annealing temperature and longer primer sequences (Qian, Ge and Hong, 2001).

The aim of this study was to test whether ISSR can provide markers to help at intraspecific or species-level decisions for taxa belonging to genus Chascolytrum lato sensu (with some taxa referred in the text as $B r i z a$, according to the existence or absence of a combination under Chascolytrum), 


\section{4}

Essi, L., et al.

whenever the study of morphological characters alone is insufficient.

The results obtained by ISSR markers are compared to previous approaches on the genus, and suggestions for applications for ISSR in the group are provided.

\section{MATERIAL AND METHODS}

The study was carried out at the Laboratory of Plant Genetics of the Universidade Federal do Rio Grande do Sul, following the procedures described in the Molecular Protocols, between the years 2006 and 2007. Plants were collected previously during field trips (from 2003 to 2006), or obtained from herbarium specimens, as described in the Taxon Sampling. Data analysis was carried out at the Laboratory of Plant Genetics of the Universidade Federal do Rio Grande do Sul and latter at the Laboratory of Taxonomy of the Universidade Federal de Santa Maria.

\section{Taxon Sampling}

Taxon sampling included representatives of two species complexes, which were analysed separately, according to morphological similarities (Table 1). The first complex (Group 1) included three species (Figures 1 and 2), and the second (Group 2) included one species (Figure 2). Twenty-five accessions were analysed, including representatives of major morphological variation found in each complex. Characters such as spikelet colour and size, lemma width, presence of trichomes, or habitat, were most often considered for sampling. Geographical information was collected, although it was not considered for sampling purposes.

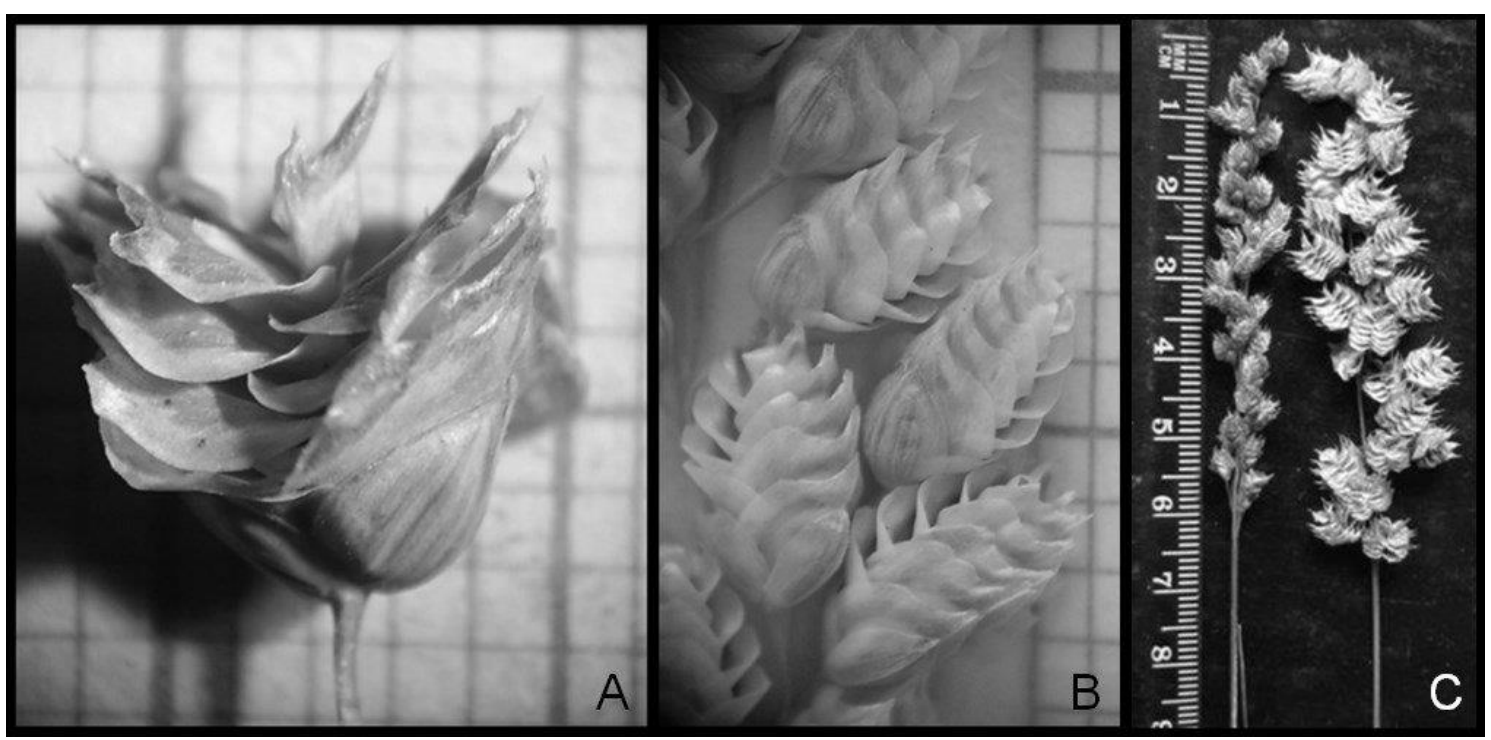

Figure 1: Comparison of specimens showing part of the morphological variability of Chascolytrum subaristatum- Size and shape variation in spikelets and panicles. A. "Briza macrostachya-like" spikelet (Voucher Information: L. Essi 13, São Pedro do Sul, RS, Brazil, 12/10/2003; ICN herbarium); B. Cylindrical type spikelets (Voucher Information: T. M. Petersen, La Yela, Dep. Empedrado, Prov. Corrientes, Argentina, 29/10/1969; S herbarium); C. Comparison between two panicles, with small spikelets (left) and big spikelets (right) - Location: São Pedro do Sul, RS, Brazil, 2003 (no voucher associated to the picture).Squares [A-B]: $1 \mathrm{~mm}^{2}$. 


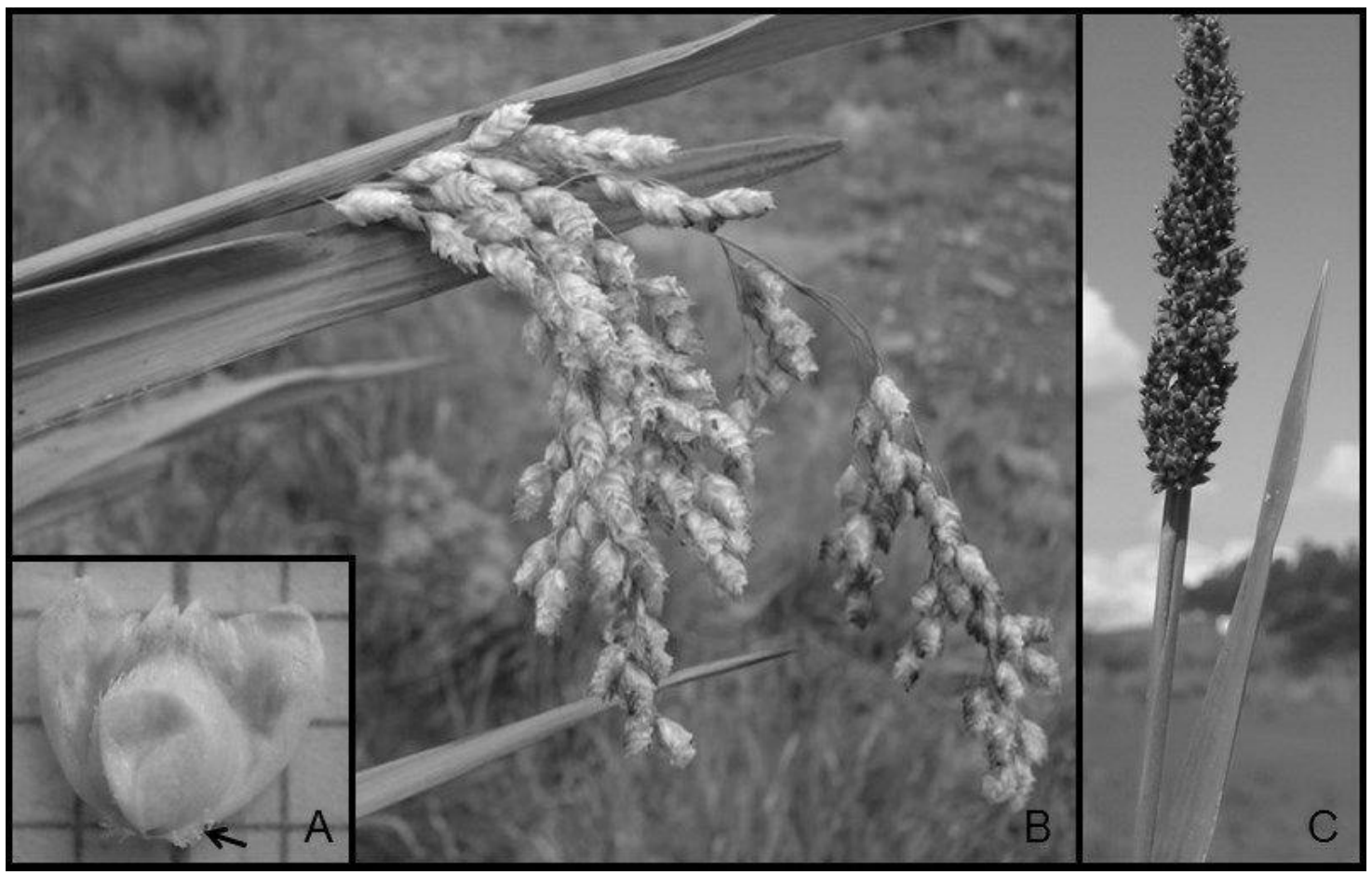

Figure 2: Species included in the analysis. A. Lema of Chascolytrum altimontanum (Group 1) - Voucher Information: Wood 10768, Oropeza, Chuquisaca, Bolivia, 25/02/1996, LPB herbarium. The arrow shows the complanate trichomes at the base of the lema, typical of the species. Squares: $1 \mathrm{~mm}^{2}$; B. Panicle of Chascolytrum latifolium (Group 1)- Picture location and date: Urubici, Santa Catarina, Brazil, 07/12/2006; Vouchers Information: Longhi-Wagner et al. 10228 - 10230, ICN herbarium; C. Panicle of Chascolytrumrufum (Group 2) - Picture location and date: Guarapuava, PR, Brazil, 16/01/2001 (no voucher associated to the picture).

Table 1: Accessions included in this study. All the taxa included are considered belonging to genus Chascolytrum; Some taxa were referred as genus Briza, when there is not yet a published combination inside Chascolytrum [one new combination submitted]. Collector's abbreviations: Hl: H. M. Longhi Wagner; Li: L. Essi; W: W. J. R. Wood.

\begin{tabular}{|c|c|c|c|}
\hline Species [morphological or habitat type] & $\begin{array}{c}\text { Collector } \\
\text { number }\end{array}$ & Voucher & $\begin{array}{l}\text { Geographical origin of the sample } \\
\text { (Country - State - Locality) }\end{array}$ \\
\hline \multicolumn{4}{|l|}{ Group 1} \\
\hline $\begin{array}{l}\text { C. subaristatum (Lam.) Desv. } \\
\text { [BrizaerectaLam.] }\end{array}$ & H15056 & ICN & Uruguay, Carrasco \\
\hline $\begin{array}{l}\text { C. subaristatum } \text { [intermediate } C \text {. } \\
\text { subaristatum- } \text {. erecta] }\end{array}$ & Li332 & ICN 149.322 & Brazil, Santa Catarina, Florianópolis \\
\hline C. subaristatum & Li7 & ICN 132.506 & Brazil, Rio Grande do Sul, Porto Alegre \\
\hline C. subaristatum & Li8 & ICN 134.887 & Brazil, Rio Grande do Sul, Porto Alegre \\
\hline C. subaristatum & Li10 & ICN 132.509 & Brazil, Rio Grande do Sul, Porto Alegre \\
\hline C. subaristatum & Li11 & ICN 132.510 & Brazil, Rio Grande do Sul, Porto Alegre \\
\hline C. subaristatum & Li12 & ICN 132.511 & Brazil, Rio Grande do Sul, Porto Alegre \\
\hline C. subaristatum & Li202 & ICN 132.542 & Brazil, Santa Catarina, Urubici \\
\hline C. subaristatum & $\mathrm{H} 15029$ & ICN & Brazil \\
\hline C. subaristatum & H15040 & ICN 131.398 & $\begin{array}{l}\text { Brazil, Rio Grande do Sul, Bagé - } \\
\text { Minas de Camaquã }\end{array}$ \\
\hline $\begin{array}{l}\text { C. subaristatum[B. subaristata var. } \\
\text { interrupta (Hack. exStuck.) Roseng., } \\
\text { Arrill. \&Izag.] }\end{array}$ & Li19 & ICN 132.518 & $\begin{array}{l}\text { Brazil, Rio Grande do Sul, São Pedro } \\
\text { do Sul }\end{array}$ \\
\hline $\begin{array}{l}\text { C. subaristatum[Briza macrostachya } \\
\text { (J. Presl) Steud.] }\end{array}$ & Li13 & ICN 132.512 & $\begin{array}{l}\text { Brazil, Rio Grande do Sul, São Pedro } \\
\text { do Sul }\end{array}$ \\
\hline C. subaristatum[Briza macrostachya] & Li18 & ICN 132.517 & Brazil, Rio Grande do Sul, São Pedro \\
\hline
\end{tabular}




\begin{tabular}{|c|c|c|c|}
\hline & & & do Sul \\
\hline C. subaristatum[Brizamacrostachya] & $\mathrm{Li} 54$ & ICN 132.553 & Brazil, Rio Grande do Sul, Piratini \\
\hline C. subaristatum[Brizamacrostachya] & Li57 & ICN 132.556 & Brazil, Rio Grande do Sul, Piratini \\
\hline C. subaristatum[Brizamacrostachya] & H15038 & ICN 131.396 & $\begin{array}{l}\text { Brazil, Rio Grande do Sul, Bagé - } \\
\text { Minas de Camaquã }\end{array}$ \\
\hline \begin{tabular}{|l} 
ChascolytrumlatifoliumEssi, Souza- \\
Chies \& \\
Longhi-Wagner \\
\end{tabular} & Li201 & ICN 132.700 & Brazil, Santa Catarina, Urubici \\
\hline $\begin{array}{l}\text { Chascolytrum altimontanum Essi, } \\
\text { Souza-Chies } \\
\text { \& Longhi-Wagner }\end{array}$ & W10768 & K, LPB & Bolivia, Chuquisaca, Oropeza \\
\hline \multicolumn{4}{|l|}{ Group 2} \\
\hline $\begin{array}{l}\text { C. rufum J. Presl var. rufum }[80 \mathrm{~cm} \text { tall } \\
\text { plant] }\end{array}$ & Li278 & ICN 134.875 & Brazil, Rio Grande do Sul, Canguçu \\
\hline C. rufum var. rufum & Li279 & ICN 134.876 & Brazil, Rio Grande do Sul, Canguçu \\
\hline C. rufum var. rufum & Li280 & ICN 134.877 & Brazil, Rio Grande do Sul, Canguçu \\
\hline C. rufumvar. rufum[broad leaves] & Li372 & ICN 132.586 & Brazil, Rio Grande do Sul, Porto Alegre \\
\hline C. rufum var. rufum [broad leaves] & Li373 & ICN 132.587 & Brazil, Rio Grande do Sul, Porto Alegre \\
\hline $\begin{array}{l}\text { C. rufum [Brizarufa var. } \\
\text { sparsipilosaRoseng., Arrill. \&Izag., } \\
\text { open panicle type] }\end{array}$ & Li281 & ICN 134.878 & Brazil, Rio Grande do Sul, Canguçu \\
\hline C. rufum [Briza rufa var. sparsipilosa] & H18061 & ICN 135.198 & $\begin{array}{l}\text { Brazil, Rio Grande do Sul, São } \\
\text { Francisco de Paula }\end{array}$ \\
\hline
\end{tabular}

\section{Molecular Protocols}

DNA was extracted from fresh, silica dried or herbarium leaves, following a CTAB method (Doyle and Doyle, 1987) adapted for micro-centrifuge tubes. Total DNA was quantified by agarose gel visualization. Thirteen primers described by Joshi et al. (2000), Martins, Tenreiro and Oliveira, (2003) and Lin et al. (2005) were tested for ISSR amplification, and nine of them were selected (Table 2). PCR reactions were carried out in an Applied Biosystems 2400 termocycler, in a total volume of $25 \mu 1$ containing $12 \mu \mathrm{l}$ sterile Milli-Q purified water, $0.2 \mu \mathrm{l}$ Taq DNA Polymerase (5U/ul), $2.3 \mu 1 \mathrm{MgCl} 2$ (25mM), $2.5 \mu \mathrm{l} 10 \times$ buffer, 1 $\mu \mathrm{l}$ primer $10 \mathrm{pmol}, 1 \mu \mathrm{l}$ of $40 \mathrm{mM}$ dNTP mixture (10mM each dNTP), $1 \mu 1$ DMSO (2\%), and $5 \mu 1$ DNA (total 30-50 ng). PCR amplifications included 40 cycles of $1 \mathrm{~min}$ at $94^{\circ} \mathrm{C}, 45 \mathrm{sec}$ at $50^{\circ} \mathrm{C}$ and $2 \mathrm{~min}$ at $72^{\circ} \mathrm{C}$, preceded by a period of $5 \mathrm{~min}$ at $92^{\circ} \mathrm{C}$ and completed by a final extension of $5 \mathrm{~min}$ at $72^{\circ} \mathrm{C}$, for all the primers, except primer F11, whose annealing temperature was $48^{\circ} \mathrm{C}$. The ISSR amplification products were stained by ethidium bromide, run until the complete separation of the ladder (100 and $50 \mathrm{bp}$, PB-L Produtos Bio-Lógicos, Universidad Nacional de Quilmes), approximately $2 \mathrm{~h} 30 \mathrm{~min}$, at $100 \mathrm{~V}$ on $1.8 \%$ agarose gel, and visualized by UV.

Table 2: Primers code and sequences included in the analyses.

\begin{tabular}{|c|c|c|}
\hline Primer code: & Primer sequence: & Described by: \\
\hline P1 & $(\mathrm{AC})_{8} \mathrm{~T}$ & Lin et al., 2005 (as 25) \\
\hline P2 & $(\mathrm{GA})_{8} \mathrm{~T}$ & Joshi et al., 2000 (as 810) \\
\hline P3 & $(\mathrm{CTC})_{4} \mathrm{RC}$ & Poulin, Weller and Sakai, 2005 (as n. 15) \\
\hline P4 & $(\mathrm{CT})_{8} \mathrm{G}$ & Joshi et al., 2000 (as 815) \\
\hline F3 & $(\mathrm{AG})_{8} \mathrm{YC}$ & Joshi et al., 2000 (as 835) \\
\hline F4 & $(\mathrm{GA})_{8} \mathrm{YC}$ & Joshi et al., 2000 (as 841) \\
\hline F7 & $(\mathrm{GT})_{8} \mathrm{~A}$ & Joshi et al., 2000 (as 819) \\
\hline F11 & $(\mathrm{GACA})_{4}$ & Lin et al., 2005 (as 73) \\
\hline F12 & $(\mathrm{GTGC})_{4}$ & Martins, Tenreiro and Oliveira, 2003 (as IS06) \\
\hline
\end{tabular}


Data analyses

Polymorph bands were scored for presence/absence. Analyses were performed using the NTSYS-pc version 2.10 software (Rohlf, 2000). For each of the two groups, the genetic similarity among individuals was calculated using Jaccard's Similarity Coefficient (J), which takes only shared presence into account. The similarity relationships were portrayed by dendrograms built using the clustering method Unweighted Pair Group Method of Arithmetic Average (UPGMA). Bootstraping analyses, with 2,000 replicates each, were performed by the Winboot software (Yap and Nelson, 1996), to access the robustness of nodes in the dendrograms, as proposed by Felsenstein (1985).

\section{RESULTS AND DISCUSSION}

For Group 1, an average of 12.66 DNA bands was produced using nine primers, $98.24 \%$ of which were found to be polymorphic. For Group 2, the average was 8.6 DNA bands, $85.89 \%$ of which were polymorphic. The group with the highest number of monomorphic bands was group 2 , with 11 bands ( $14.11 \%$ of the matrix). The primer with the smallest number of bands, considering both complexes, was F7 (total of 7 bands), and the highest number of bands was obtained with the primer P4 (total of 31 bands).

The Jaccard similarity index ranged from 0.2260 , between accession li201 and accession w10768, to 0.7442 , between accessionHw5038 and accessionHw5056. Low levels of similarity were found in both groups. The absence of a similarity index of 1.0 indicates that no clone or repeated germplasm was included, and all accessions represent plants with distinct fingerprints. The limits for the acceptance of the clusters were established by the similarity average inside the group (see values of the averages for each group in Figures 3 and 4).

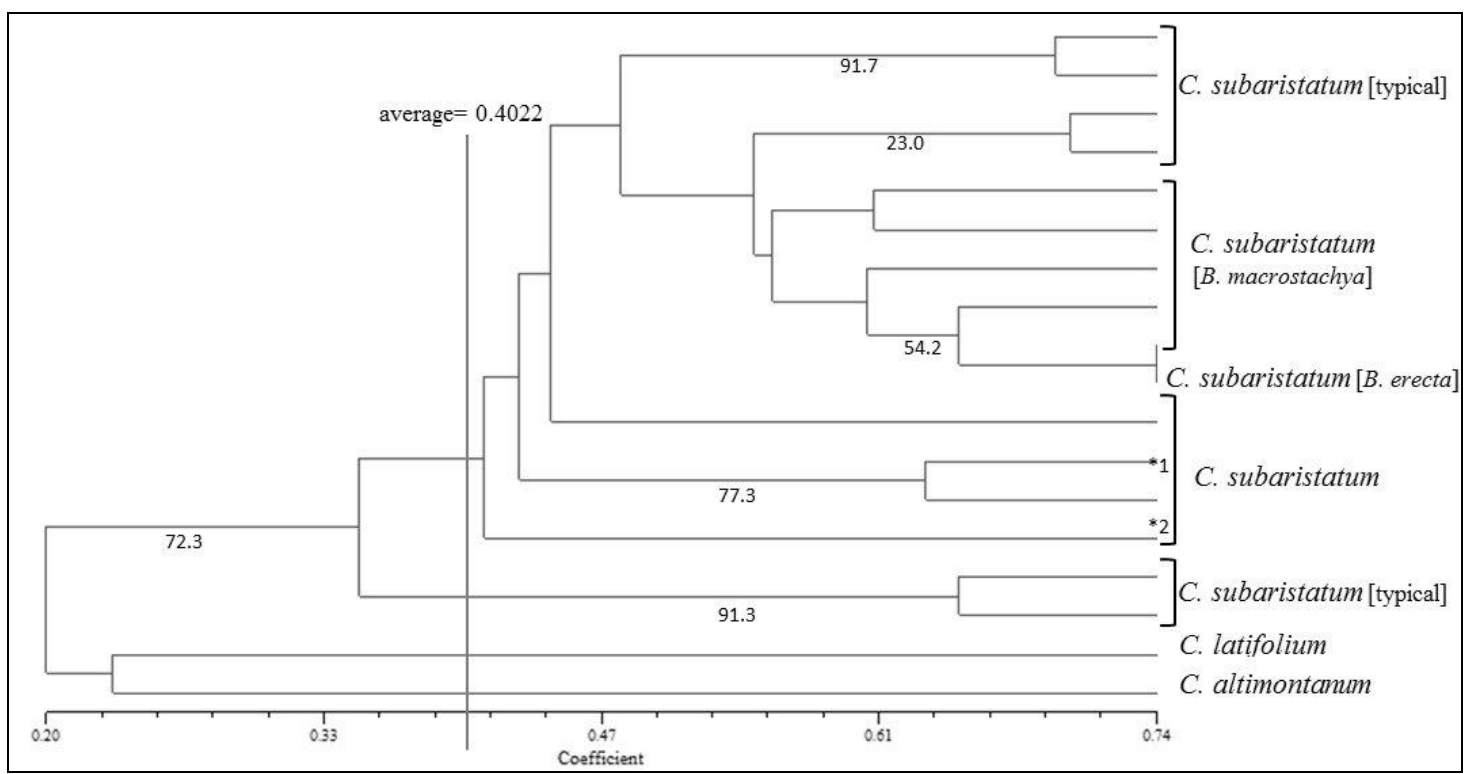

Figure 3: UPGMA dendrogram of individuals from group 1. The cluster is based on the Jaccard similarity index. Vertical line marks the average of similarity indexes. ${ }^{*} 1=$ C. subaristatum [B. subaristata var. interrupta (Hack. ex Stuck.) Roseng., Arrill. \& Izag.]; *2=C. subaristatum [intermediate $C$. subaristatum- B. erecta] Numbers below branches correspond to bootstrap values $>50$.

In Group 1, the two recently described species (accessions li201 and w10768) appeared very distinct from the remaining taxa, being grouped with a very low similarity index. The two are distinct taxa, and grouped together probably due to the absence of other more closely related accessions. All other accessions appeared clustered. Although the grouping between Cluster A and Cluster B is under the similarity average for the group, it is supported by bootstrap. The high similarity among accessions of Briza macrostachya and the accession of $B$. erecta is also supported by bootstrap. 


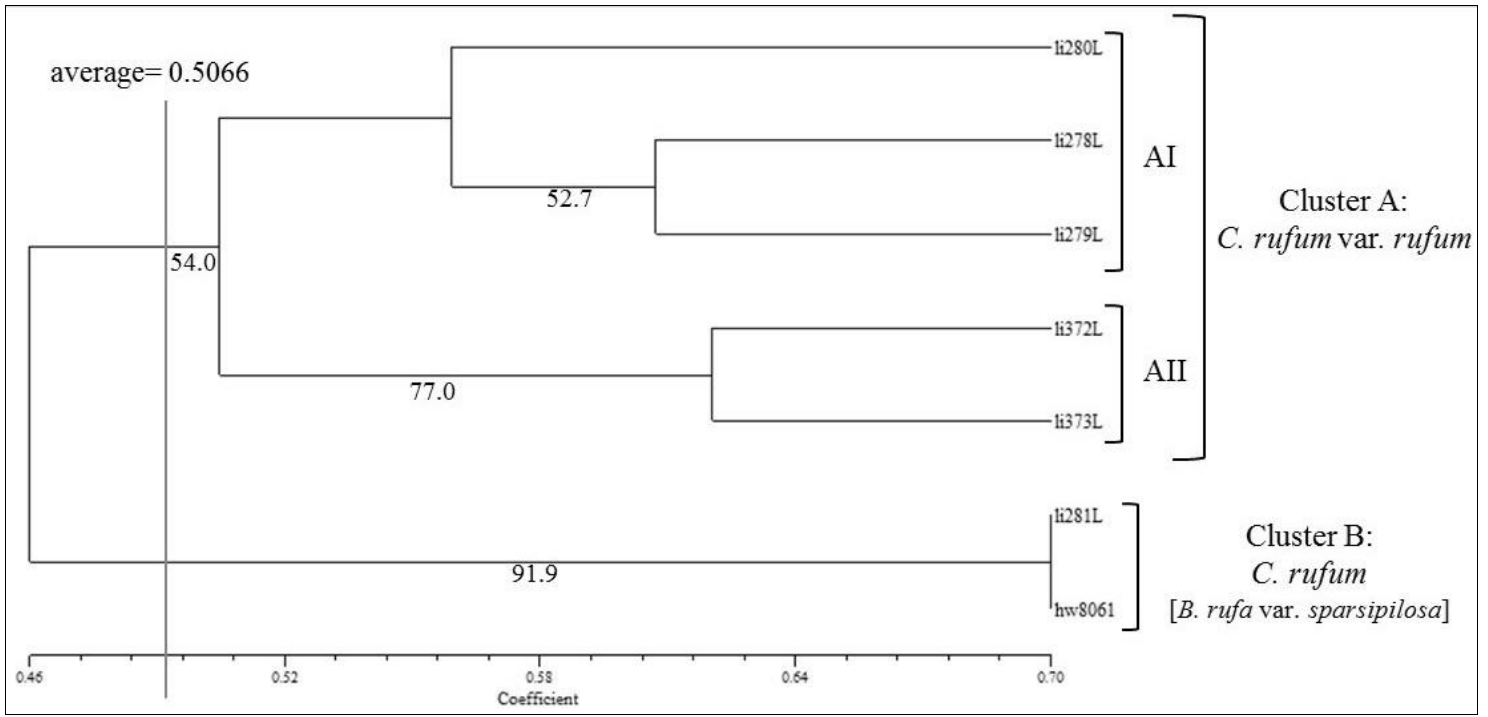

Figure 4: UPGMA dendrogram of individuals from group 2. The cluster is based on the Jaccard similarity index. Vertical line marks the average of similarity indexes. Numbers below branches correspond to bootstrap values $>50$.

In Group 2, the two varieties could be separated, being variety sparsipilosa grouped with the highest similarity level (Cluster B), in spite of its different geographical origins. The main clusters (A and $\mathrm{B}$ ) represent the two varieties, and the secondary clusters follow a geographical order (AI: Canguçu; AII: Porto Alegre).

Low similarity levels were already expected, due to two main factors: 1) The ISSR are one of the most polymorphic molecular markers; 2) Chascolytrum species are autogamous, mainly cleistogamous, so that a low intrapopulation variability and a high interpopulation variability were expected. Although a high level of polymorphism was not a surprise, the use of ISSR as a species marker was not possible: only one band was exclusive of a particular analysed species (however not exclusive when comparing to other Chascolytrum species, not included in this paper - data not show), and the similarity indexes were lower than those usually published for species-complexes. Their use as phylogenetic markers for Chascolytrum should be avoided, since a minimum monomorphism (20\%) across all taxa is required to consider the markers potentially homologous to such studies (Bussell, Waycott and Chappill, 2005). The ISSR helped to solve some critical questions:

1) Concerning the acceptance of two varieties for Chascolytrum rufum: ISSR data supported the recognition of two genetically distinct groups, which correspond to the two varieties sampled. This is also in agreement with other approaches based on flavonoid variation, pollen and satellite chromosomes position (Winge et al., 1984).

2) Concerning the robustness of recently described species: The accessions sampled were absolutely distinct from the remaining morphologically related accessions, thus supporting their acceptance as distinct species, in addition to the morphological findings.

3) Concerning the circumscription for the Briza macrostachya- B. erecta - $C$. subaristatum complex: The obtained data place $B$. erecta asgenetically very close to $B$. macrostachya, a relation supported by bootstrap. This is in agreement with the opinion of Matthei (1975), who considered these two species synonymous. But the different accessions of $C$. subaristatum are widespread over the clusters, producing the same impact caused by morphological analysis - not only $B$. macrostachya and $B$. erecta should be synonymised, but all three, $B$. erecta and B. macrostachya considered an intra-specific polymorphism. This idea may appear not convincing morphologically considering the analysis of the Uruguayan material of $B$. erecta, but it is perfectly acceptable when the Brazilian material is studied. Different spikelet sizes (mature spikelets) are commonly found in the same 
plant. And the material usually identified as $B$. erecta is collected mostly in sandy soils. In the case of this complex, a study observing the morphology under different environmental conditions and through different plant generations would be useful to check the influence of the environment on the colour and size of the spikelets, which are the main characters used to distinguish species from this complex. If the three species are accepted as distinct taxonomic entities, it is necessary to consider the hypothesis of hybridization among the species, due to intermediates types. The results obtained for this complex contradict the results of Winge et al. (1984), which allowed the differentiation of the three species, and influenced the circumscription published by LonghiWagner (1987). Although their sampling was broader (average of ten individuals per species), it is important to emphasize that some of the markers utilized (morphological, isoesterases) are more affected by environmental conditions than the ISSR markers - which could be the main cause of the distinct phenotypes. Future works with ISSR should include a broader sampling of these three species and greenhouse essays.

\section{CONCLUSIONS}

Concluding, ISSR are useful as a tool to support taxonomic decisions in genus Chascolytrum, but it is important to keep in mind that ISSR are more effective as markers for polymorphism than for conservative features in this genus.

\section{ACKNOWLEDGMENTS}

We thank the researchers who kindly contributed with plant samples to this molecular survey (Robert Soreng, and Stephan Beck), the financial support provided by CNPq and FAPERGS, the PhD fellowship provided by $\mathrm{CNPq}$ and the facilities provided by the Department of Genetics at UFRGS-Federal University of Rio Grande do Sul. We also thank Gustavo Agostini and Fernanda Cidade, for their invaluable help with the technique.

\section{REFERENCES}

ALEXANDER, J., LISTON, A., POPOVICH, $S$. Genetic diversity of the narrow endemic Astragalus oniciformis (Fabaceae). American Journal of Botany, v. 91, p. 2004 - 2012, 2004.

AYRES, D.R., STRONG, D.R. Origin and genetic diversity of Spartina anglica (Poaceae) using nuclear DNA markers. American Journal of Botany, v. 88, n. 10, p. 1863 - 1867. 2001.

BLAIR, M. W., PANAUD, O., MCCOUCH, S.R. Inter-simple sequence repeat (ISSR) amplification for analysis of microsatellites motif frequency and fingerprinting in rice (Oryza sativa L.). Theoretical and Applied Genetics, v. 98, p. 780 - 792, 1999.

BUSSELL, J. D., WAYCOTT, M., CHAPPILL, J. A. Arbitrarily amplified DNA markers as characters for phylogenetic inference. Perspectives in Plant Ecology, Evolution and Systematics, v. 7, p. 3 - 26, 2005.

DINELLI, G. Characterization of Italian populations of Lolium spp. resistant and susceptible to diclofop by inter simple sequence repeat. Weed Science, v. 52, p. 554 - 563, 2004.

DOYLE, J. D., DOYLE, J. L. A rapid DNA isolation procedure for small quantities of fresh leaf tissue. Phytochemical Bulletin, v. 19, p. 11 $-15,1987$.

ESSELMAN, E. J. et al. Clonal diversity in the rare Calamagrostis porteri ssp. insperata (Poaceae): comparative results for allozymes and random amplified polymorphic DNA (RAPD) and inter simple sequence repeat (ISSR) markers. Molecular Ecology, v. 8, p. 443-451, 1999.

ESSI, L., LONGHI-WAGNER, H. M., SOUZA-CHIES, T. T. Phylogenetic analysis of the Briza Complex (Poaceae). Molecular Phylogenetics and Evolution, v. 47, p. 10181029. 2008.

ESSI, L., LONGHI-WAGNER, H. M., SOUZA-CHIES, T. T. New Combinations Within the Briza Complex (Poaceae, Pooideae, Poeae). Novon, v. 21, n. 3, p. 326 - 330, 2011.

FELSENSTEIN, J. Confidence limits on phylogenies: an approach using the bootstrap. Evolution, v. 39, p. 783 - 791, 1985. 
JOSHI, S. P. et al. Genetic diversity and phylogenetic relationship as revealed by Inter Simple Sequence Repeat (ISSR) polymorphism in the genus Oryza. Theoretical and Applied Genetics, v. 100, p. $1311-1320,2000$.

LI, A., GE, S.Genetic Variation and Clonal Diversity of Psammochloavillosa (Poaceae) Detected by ISSR Markers. Annals of Botany, v. 87, p. 585 - 590, 2001.

LIN, W. X. et al.Use of ISSR molecular marker approach to estimate genetic diversity in rice and barley allelopathy. Proceedings of the 4th World Congress on Allelopathy, eds. HARPER, J. D. I, AN, M., WU, H. AND KENT, J. H. Charles Sturt University, WaggaWagga, NSW, Australia. August 2005. International Allelopathy Society.

LONGHI-WAGNER, H. M. Flora Ilustrada do Rio Grande do Sul, Fasc. 17. Gramineae. Tribo Poeae. Boletim do Instituto de Biociências, v. 41, p. 1 - 191, 1987.

MARTINS, M., TENREIRO, R., OLIVEIRA, M. M. Genetic relatedness of Portuguese almond cultivars assessed by RAPD and ISSR markers. Plant Cell Report, v. 22, p. $71-78$, 2003.

MATTHEI, O. Der Briza-Komplex in Südamerika: Briza, Calotheca, Chascolytrum, Poidium (Gramineae). Willdenowia, v. 8, p. 7 168,1975

MATTIONI, C. et al. Comparison of ISSR and RAPD markers to characterize three Chilean Nothofagus species. Theoretical and Applied Genetics, v. 104, p. 1064 - 1070, 2002.

POULIN, J., WELLER, S. G., SAKAI, A. K. Genetic diversity does not affect the invasiveness of fountain grass (Pennisetum setaceum) in Arizona, California and Hawaii. Diversity and Distribution, v. 11 , p. $241-247$, 2005.

QIAN, W., GE, S., HONG, D-Y. Genetic variation within and among populations of a wild rice Oryza granulata from China detected by RAPD and ISSR markers. Theoretical and Applied Genetics, v. 102, p. 440 - 449, 2001.

SOUZA, V. Q. et al. Dissimilaridade genética em mutantes de aveia tolerantes e sensíveis a ácidos orgânicos. Bragantia, v. 64, n. 4, p. 569 $-575,2005$.
ROHLF, F. J.NTSYS-pc: numerical taxonomy and multivariate analysis system, version 2.10 New York: Exeter Software, 2000.

SONG, Z. et al. Inter-simple sequence repeat (ISSR) variation in populations of the cutgrass Leersiahexandra. Aquatic Botany, v. 84, p. 359-362, 2006.

VANDERPOORTEN, A., HEDENÄS, L., JACQUEMART, A-L. Differentiation in DNA fingerprinting and morphology among species of the pleurocarpous moss genus, Rhytidiadelphus (Hylocomiaceae). Taxon, v. 52, p. 229 - 236, 2003.

VERGARA, R. et al. Preliminary Study Using ISSRs to Differentiate Imperata Taxa (Poaceae: Andropogoneae) Growing in the US. Southeastern Naturalist, v. 7, n. 2, p. 267 276, 2008.

WINGE, H. et al. Sistemática e evolução das espécies sul-americanas do Complexo Briza (Gramineae). In: Colóquio Sobre Citogenética e Evolução de Plantas, 1. Sociedade Brasileira de Genética, Piracicaba, p. 185 - 203, 1984.

WU, C. et al. Genetic diversity among and within populations of Oryza granulata from Yunnan of China revealed by RAPD and ISSR markers: implications for conservation of endangered species. Plant Science, v. 167, p. 35 $-42,2004$.

YAP, I. V., NELSON, R. J. Winboot: a program for performing bootstrap analysis of binary data to determinate the confidence limits of UPGMA-based dendrograms. Manila: IRRI. 22p. 1996.

ZHANG, Q. X. et al. Genetic diversity of natural Miscanthussinensis populations in China revealed by ISSR markers. Biochemical Systematics and Ecology, v. 48, p. 248-256, 2013.

ZIETKIEWICZ, E., RAFALSKI, A., LABUDA, D. Genome fingerprinting by simple sequence repeat (SSR)-anchored polymerase chain reaction amplification. Genomics, v. 20, p. $176-183,1994$.
Recebido: 20/02/2014

Received: 02/20/2014

Aprovado: 10/04/2014

Approved: 04/10/2014 